\title{
In Search of a Sympathetic Liberalism in Adam Smith
}

\section{Alves Costa $\mathrm{T}^{*}$ \\ Universidade Federal de Pelotas, Brazil}

*Corresponding author: Thais Alves Costa, Universidade Federal de Pelotas, 3031, av. Bento Gonçalves, Centro, Pelotas, RS. 9615-145, Brazil, Tel: +5553991557631; Email: costa. thaisalves@gmail.com

\section{Research article}

Volume 4 Issue 2

Received Date: May 11, 2021

Published Date: June 11, 2021

DOI: $10.23880 /$ phij-16000183

\section{Abstract}

The mainstream view of the twentieth century suggests that Adam Smith made a tout court defense of laissez-faire and a pure rational calculation of Economics. However, I consider this a biased interpretation that ignores an integrated reading of his works, The Theory of Moral Sentiments (1759) and Wealth of Nations (1776). In opposition to this dominant view, I propose as a methodological strategy - a systematic analysis of Smith's thought that encompasses the moral, economic, and political dimensions in what I call a tripartite theory. Although these three dimensions are connected, I argue the moral dimension is the Archimedean point of his theory, since Smith's system is based on the moral sentiment of sympathy. From the moral point of view, sympathy is understood as a kind of "organic connection" between people, for it allows the individual to put himself in another's place using the device of the imagination. Through this movement, it is possible to feel, to some extent, how another feels, enabling self-knowledge and the recognition of the other as an equal. From an economic point of view, I need to keep in mind that one of the fundamental points of Smith's theory is the understanding that self-interest cannot be considered only the feeling that moves interpersonal relationships. There is the feeling of mutual trust, which is a condition for commercial relations and economic progress. The political dimension excels in virtuous societies and, for that, requires cooperative subjects and fair behavior. The need for sympathy occurs, in this sphere, with a view to promoting the recognition of the other that generates individuals morally engaged in cooperating. In the end, I intend to defend that the sympathetic liberalism that I find in Smith's tripartite vision is a political model capable of contributing to promote a prosperous society.

Keywords: Moral; Economy; Politics; Sympathy; Tripartite theory

\section{Introduction}

Is it possible to imagine a political and economic liberalism that can deal with contemporary social problems, such as reduction of inequalities among people, economic crises and political intolerances? In an attempt to find a viable alternative to mitigate such issues, I turn to Adam Smith's theory to propose what I call sympathetic liberalism. In this regard, I will start from the idea that the moral dimension from Adam Smith's philosophical corpus provides the balance between the economic and political spheres of his line of thought. For this reason, the Smithian theory must be comprehended from a combined reading of his books $A n$ Inquiry into the Nature and Causes of the Wealth of Nations (Wealth of Nations, 1776) and The Theory of Moral Sentiments (1759), in which morally supports economics and politics in a tripartite theory.

\section{Section 01: The moral point of view}

According to Adam Smith, the morality behind human actions is essentially practical and based on the feeling of 


\section{Philosophy International Journal}

sympathy. As a result, it cannot be understood as something that starts from metaphysics, but as part of practical human life $^{1}$. In this sense, all and every experience on which the general rules of human are objects originate from immediate sense and feeling and not from reason. Based on this, sympathy is understood as a concept that arises from the analysis of real sentiments, that is, the way people with their life experiences in society, incorporate meanings of morality. This view is so important that Smith begins his book, The Theory of Moral Sentiments (1759) with the following statement:

How selfish soever man may be supposed, there are evidently some principles in his nature, which interest him in the fortune of others, and render their happiness necessary to him, though he derives nothing from it except the pleasure of seeing it. (....) is a matter of fact too obvious to require any instances to prove it; for this sentiment, like all the other original passions of human nature, is by no means confined to the virtuous and humane, though they perhaps may feel it with the most exquisite sensibility. The greatest ruffian, the most hardened violator of the laws of society, is not altogether without it. ${ }^{2}$

From the moral point of view, sympathy ${ }^{3}$ is the

1 Starting from this defense, we would not speak of good and bad in terms of action metaphysics. However, in terms of correct and incorrect or adequate and inadequate guidance by this moral feeling that goes beyond the rationalist dimension, revealing a human nature in which our moral sensitivity is acquired and evolved over time.

2 Smith, 1759:05.

3 See: Smith, 1759: 8. As for the understanding of the Locus of sympathy, it is worth highlighting three classic evolutionary theories, namely: A. Classical Genetic Perspective; B. Evolutionary Theory of Natural Selection; C. Cultural Interaction, each offering different moral developments about the origin of sympathy. For example, according to the Classical Genetic Perspective (A), the genetic basis is responsible for establishing the behavioral dispositions of the agent. Based on the Classic Molecular concept, the gene is the segment of DNA that encodes a certain function in the biological system, with a specific functionality that determines the structural and functional characteristics in an innate way. Starting from this idea, human behavior would be determined in advance based on his or her genetics. In this sense, the levels of sympathy would be genetically predetermined, which could make the possibility of teaching and promoting sympathy somewhat irrelevant. While the Evolutionary Theory of Natural Selection (B) will defend that, appearing as an evolutionary adaptation mechanism, sympathy is motivated by self-interest. Seen in these terms, cooperation occurs selfishly with a view to the offspring's survival. Learned by imitation, sympathy goes, over time, being registered in memory. Finally, the Cultural Interaction (C) endorses that sympathy originates from cultural variants elaborated from patterns of behavior, represented cognitively and passed on from generation to generation. In this case, culture consists of the manifestation of a set of material and ideological phenomena that characterize an ethnic group, that is, a civilization with language, gestures and clothing that express their experiences. Thus, sympathy would be developed through cultural interactions and their motivation would not be based on self-interest, but cooperation. Cf. Williams, 1960; Street, 2006:172; Porting, 1993:173; Keller, 2005:101; Fogle, 1990; Guimarães; Moreira, 2000:249; Venter, 2001. fundamental feeling that motivates human behavior and, through the engagement of the imagination, promotes a kind of "organic connection" via fellow-feelings. In this sense, sympathy in Smith can be understood in two ways, namely: $i$. as something direct and mechanical and ii. as something indirect and sensitive $e^{4}$. The first modality of sympathy (i.) consists of the immediate reaction to a given stimulus. I can imagine, for instance, when someone is greeted with a big grin by the university cafe attendant and automatically feels compelled to respond back with a smile. This phenomenon occurs because, according to Smith, "grief and joy, for example, strongly expressed in the look and gestures of any one, at once affect the spectator with some degree of a like painful or agreeable emotion". ${ }^{5}$ That way, it is possible to perceive this mechanical movement, since a happy face makes us happy and a sad one distresses us without rationalizing our action. ${ }^{6}$ In addition, it is possible to automatically have confidence in another person through simple gestures such as an honest look or a firm handshake.

When we see a stroke aimed and just ready to fall upon the leg or arm of another person, we naturally shrink and draw back our own leg or our own arm; and when it does fall, we feel it in some measure, and are hurt by it as well as the sufferer. The mob, when they are gazing at a dancer on the slack rope, naturally writhe and twist and balance their own bodies, as they see him do, and as they feel that they

4 See: Darwall, 1999; Sayre-McCord, 2014.

5 Smith, 1759:8.

6 There are several experiments that study the relationship of empathy between people, its origins and developments. Among them, some stand out. For example, Hatfields carried out studies that aimed to measure the levels of sympathy and its relationship with possible genetic dispositions of the agents. To perform the tests, a "quantitative trait" was established in which it was possible to statistically relate the performance of each participant with their genome. Through this relationship, it was found that most of the people involved had average levels of sympathy. However, some were detected with extreme levels, which was directly associated with pathologies such as, at a low level, autism and psychopathy and at a high level Williams syndrome. In contrast, last year the results of the largest genetic study on sympathy were released, involving more than 46,000 people. After careful observation of 10 million genetic variants, it was discovered that these collectively contribute to about $10 \%$ of differences in sympathy levels. For one hand, this result demonstrated that our sympathy is partly due to genetics. On the other hand, the percentage variation represented only one tenth in the whole of the formation of human behavior. There are also the experiments by Preston and Waal that associate sympathy and imitation arguing that both share the same motivational structure. So, it similarly involves shared representations, identification by physical similarity, automaticity and spontaneity. These shared representations are easily found in nature. For example, there are indications that Chimpanzees have already imitated acts such as yawning, scratching and the sight of others who eat. Baby monkeys already imitate facial expressions just like human babies do. The relationship between observation and imitation is supported by neurophysiological data regarding emotional facial behavior: both are activated by the same group of brain structures, including the aortic premotor cortex, the insula and the amygdala, as noted by Waal. See: Preston; Waal, 2002, Laland, K .; Brown. 2002, Bard, 2007. 


\section{Philosophy International Journal}

themselves must do if in his situation. ${ }^{7}$

On the other hand, sympathy can be felt as something sensitive and directed (ii.) That occurs when we put ourselves in someone else's place. This arrangement allows us to better understand the situation a person is going through. When I see someone who is sad, I do not automatically put myself in her or his position, unless I understand the situation which this person is experiencing. If this person is sad for having lost a loved one, this situation is much stronger and more comprehensive that allows us to put ourselves in the other's shoes. Imagine Carla's situation, a Balzac woman who hates children and has never pictured herself as a mother. During a bus trip, a pitiful woman sits beside her. The woman is sad because she has just lost her only child. Although Carla had never imagined having children, she still feels connected to that mother's pain. Carla will never be able to feel exactly that maternal pain, for such grief is exclusive to those who feel it. However, even in the face of all circumstances, Carla sympathizes with that pain.

Smith admits that human beings are distinct and, therefore, will never know or feel exactly someone else's pain. I may regret one's pain, but that pain belongs to the person. Faced with this reality, sympathizing occurs from the feeling formed by the idea about what happens in a certain situation. Therefore, the only way we can form this idea is by assuming ourselves in identical circumstances, wondering how we would react in those cases. However, it is impossible for us to put ourselves in any situation, pleasant or not, without feeling an effect similar to what this situation would produce in ourselves. Consequently, the attention that we pay, at a certain moment, to someone else's circumstances should affect us in a similar way, what suggests that "our imagination imitates the impression of our own senses". According to Smith, it is through the device of the imagination ${ }^{9}$

\section{Smith, 1759:6.}

8 Smith, 1759:8. "They never did, and never can, carry us beyond our own person, and it is by the imagination only that we can form any conception of what his sensations are. Neither can that faculty help us to this any other way, than by representing to us what would be our own, if we were in his case. It is the impressions of our own senses only, not those of his, which our imaginations copy. By the imagination we place ourselves in his situation, we conceive ourselves enduring all the same torments, we enter as it were into his body, and become in some measure the same person with him, and thence form some idea of his sensations, and even feel something which, though weaker in degree, is not altogether unlike them. His agonies, when they are thus brought home to ourselves, when we have thus adopted and made them our own, begin at last to affect us, and we then tremble and shudder at the thought of what he feels. For as to be in pain or distress of any kind excites the most excessive sorrow, so to conceive or to imagine that we are in it, excites some degree of the same emotion, in proportion to the vivacity or dullness of the conception".(Smith, 1759:8).

9 The set of our senses (external and internal), by itself, cannot take us beyond ourselves. In order to overcome the narrowness of individual emotional reaction, imagination must enter the scene, projecting us beyond that we can put ourselves in other people's places and, in this projection, we connect to them. Smith says, in all the passions to which the human spirit is susceptible, the emotions of the observer when placing himself in the same circumstances will always correspond to the feelings he imagines would be that of those who suffer. ${ }^{10}$ Our cognitive abilities allow us to escape imaginatively to someone else's life "we blush for the impudence and rudeness of another", ${ }^{11}$ providing a means of gaining perspective on his world.

Although this device of imagination allows us to connect with others, it suffers from the problem of partiality. To work around this problem, alongside the condition of sympathy in relationships, Smith resort the notion of the impartial spectator $^{12}$ to justify moral judgment. This judgment is what he calls behavioral property, which revolves around the question about the mechanism of an agent and the patient's reaction to be appropriate or not. To do this, we use our cognitive abilities to assume, not an external perspective, but either the standpoint from the agent performing the action or the patient receiving it. We do this by imaginatively projecting ourselves into their lives, and by doing it in an impartial ${ }^{13}$ manner we can assume the full repertoire of their thoughts, emotions, and deeds.

Smith correlates the approval or disapproval with which we judge both our conduct of and the other people with the

our empirical situation. In this sense, "By the imagination we place ourselves in his situation, we conceive ourselves enduring all the same torments, we enter as it were into his body, and become in some measure the same person with him, and thence form some idea of his sensations, and even feel something which, though weaker in degree, is not altogether unlike them" (Smith, 1759:9). Imagination or fantasy is the human faculty capable of putting us in someone else's shoes. We are able to imagine ourselves in the most varied situations and to assume the most varied roles (we can imagine ourselves as historical or even fictional characters, we can even imagine ourselves as animals and inanimate objects) and to experience them in a represented way.

10 In some cases, sympathy manifests as a kind of solidarity between different people, which, in turn, is always pleasing to both people. This is called mutual sympathy. When I am in a situation that excites any passion, it is pleasant to know that those who follow my situation experience with me all their various circumstances and are affected by them in the same way that I am. On the other hand, it is pleasant for the viewer to observe this correspondence between his emotions and mine. For that reason, moral judgment is a mechanism that drives identification and, as we evaluate others morally, we necessarily identify with them. See: Smith, "Of the pleasure of mutual Sympathy" chapter of The Theory of Moral Sentiments.

11 Smith, 1759:121.

12 In addressing our general flaws of judgment, Smith argues that nature: "when she implanted the seeds of this irregularity in the human breast, seems upon all other occasions, to have intended the happiness and perfection of the species" (Smith, 1776: 105). The development of the impartial spectator is understood then as part of this perfection.

13 According to Darwall, there is an emphatic need for impartiality in the Smithian spectator, since moral judgments are "deeply individual-relativeeither agent-relative or patient-relative or both". (Darwall, 1999: 142). 


\section{Philosophy International Journal}

necessity of distance to observe the action. This movement allows observing the action adequately. Since the judgment of convenience (adequacy) or inconvenience is related to the fact that an action is adequate or inadequate according to the cause that inspired the agent to perform it. The judgment is first performed by the spectator of an action, when imagining himself in the agent's place. After this primary judgment, the spectator compares the motivational feeling resulting from this action with the feeling that he himself would have had if he were the agent. If, in the imagined situation, the spectator had the same attitude as the subject on trial, then he would share his feelings and would therefore approve the action $^{14}$. The opposite is manifested if the agent who observes the situation has a feeling averse to it, condemning it.

In this sense, detachment makes it easier to analyze action and conduct. In the same way as when we place an object very close to the eyes it seems distorted, when we analyze our conduct ourselves, a distorted perspective is also obtained, since, being very close, the tendency is for the subject to look at himself with a certain condescension. Smith says, "We can never inspect our own feelings and motives, we can never form any judgment about them, except abandoning, as it were, our natural position and trying to see them as if they were some distance away from us". ${ }^{15}$ The way to avoid incurring this bias may be via an inspection of one's own actions and conduct based not only on how likely other people would see them, but by examining them as it is thought that an impartial and incorruptible viewer would judge them. The impartial spectator will be the superior judge of my own actions, and of the actions and moral judgments of others. ${ }^{16}$ If it is conferred on me and the other the power to judge our fellow human, by nature it will not be given to them or to me the last word on the right or wrong, the adequacy or inadequacy of my feelings (moral judgments) and actions. It will be up to the impartial spectator - an ideal judge who inspires everyone, but who empirically does not identify with anyone - to be the ultimate arbiter. This condition of impartiality offers the ideal standard of morality from which we could define a moral yardstick for our actions.

Such method allows us not only to evaluate the behavior of others, but also our own ${ }^{17}$. The device of the impartial

14 For Sayre-McCord, "The pleasure we take in being in sympathy with others - the pleasure of approving of others - works also, Smith thinks, to shape our own sentiments (or at least our willingness to show them) so as to make them more likely to be sympathized with by others" (2018:224). See: Sayre-McCord, 2014, 2018 e 2010.

15 Smith, 1759:139.

16 This is due to the fact that Smith deals with the question as a reflective character.

17 From a practical point of view, we consider our acts morally good or bad (appropriate or inappropriate) depending on the feelings that motivate them. This type of moral metric used by the moral sentimentalist starts from spectator is employed to set references to our own conduct by projecting ourselves in the place of those who will be at the end of our actions, that is, as patients or observers of our own reactions. A behavior or reaction is then judged as moral or immoral considering the impartiality of decision making from the spectator, since such a viewer is used as a strategy for ethical justification. In turn, this "transposition of bodies" will allow the recognition of the other as well as our self-knowledge. That is, not only to feel what the other feels, but also to feel what we would feel if we were the other, recognizing the other as one just like me at the same time that I know myself.

Furthermore, the merit or demerit of an action is considered a consequence of the approval (convenience) or disapproval (inconvenience) of the spectator, which also allows us to distinguish the moral qualities of the action by its respective relationship with patients ${ }^{18}$. In this sense, merit or demerit is the effect that affection tends to produce, based on the notion of justice. When the tendency of an emotion is pleasure, the agent seems to be an appropriate object of reward; in turn, when it is painful, the agent seems to us an appropriate object of punishment. Such judgments of adequacy or inadequacy will promote a feeling of justice or injustice.

Therefore, holding that a person deserves reward or punishment is the same as stating that such a person is an adequate object of gratitude or resentment, respectively. This natural feeling makes us capable of judgment. The sentiment of justice or injustice that comes via impartial spectator`s moral judgment will settle the law and rules of coexistence. ${ }^{19}$ Thus, this view would make all moral judgments profoundly relative to the agent or patient. When we judge an agent's motive, we do it from the agent's own perspective (properly regulated), visualizing the practical situation as we imagine confronting it in a state of deliberation. And when the moral

the assumption that the evaluation stems from the fact that human nature has two basic characteristics. First, all individuals are endowed with a sense of self-love and benevolence. Second, we have some cognitive control over our emotions, thinking and behavior. Morrow (1924), Dupuy (1992), and Dumond (1977). From this, the sentimentalist bases their theory.

18 The agent will be the one who acts and the actions can be judged according to their own values, motivations and objectives, regardless of external evaluations. One of the developments of the idea of Smith's agent will be Amartya Sen's conception of agency (condition of agent). On the other hand, the patient and the one who suffers an action. (Sen, 2011). For Raphael, "Smith holds that to judge whether a motive or feeling is warranted or proper, we must take up, not some external perspective, but that of the person who has the motive or feeling-the agent's standpoint, in the case of motivation; the patient's standpoint, in the case of feeling'. (Raphael, 2007, p. 31).

19 Darwall says "Punishment aims to make the other "sensible" of our dignity, to feel respect for us. Smith's view of the equal dignity of individuals provides much of the moral underpinning for his praise of free markets in The Wealth of Nations". (Darwall, 1999:154). 


\section{Philosophy International Journal}

community judges someone's feeling or reaction, he does it from a patient-related point of view, seeing the situation how we imagine it to confront the patient who responds to him. This notion of justice that allows the connection between the viewer and the agent/patient engenders a type of moral human equality. Given this, the notion of justice would promote the feeling of recognizing one's dignity, as it can strongly influence the way we perceive and act.

This whole process regulated by the moral principle of impartiality will enable us to renounce our egocentric feelings and assume without prejudice the interests and feelings of each relevant party of the situation we are judging. ${ }^{20}$ There can be situations where individual interests conflict with the interests of others. In such cases, self-control ${ }^{21}$ must be used as the virtue capable of dealing with the natural emotion of self-interest, reconciling it with the interests of others via sympathy. ${ }^{22}$ In this sense, we discover ourselves as equals and,

when we prefer ourselves so shamefully and so blindly to others, we become the proper objects of resentment, abhorrence, and execration. It is from him only that we learn the real littleness of ourselves, and of whatever relates to ourselves, and the natural misrepresentations of self-love can be corrected only by the eye of this impartial spectator. It is he who shows us the propriety of generosity and the deformity of injustice; the propriety of resigning the greatest interests of our own, for the yet greater interests of others, and the deformity of doing the smallest injury to another, in order to obtain the greatest benefit to ourselves. ${ }^{23}$

In short, having self-control is essentially feeling for yourself just what others can feel. On that account, the impartial spectator has "reason, principle, conscience" 24 and the ability to reveal ourselves as "we are but one of the multitudes, in no respect better than any other in it". ${ }^{25}$ We have, therefore, an analysis of the moral psychology of the agent in Smithian thought expressed in the relationship between motivation and morality, which depends on the point of support for the theory urges in its discussion. Consequently, in Smith's sentimentalism, a natural motivation based on sympathy can guide us toward fair behaviors which would

\section{See Darwall, 1999.}

21 Adam Smith's so-called social virtues are the civic virtues of justice, prudence, self-control and benevolence. Check out: Smith, 1759.

22 In this sense, the notion of humanity and self-control for Smith "constitutes the perfection of human nature" (Cf. Raphael, 2007), as they allow feelings of altruism or self-sacrifice based on the recognition and appreciation of the other.

23 Smith, 1759: 137.

24 Smith, 1759: 137.

25 Smith, 1759: 137. therefore engender a virtuous society. ${ }^{26}$

\section{Section 02: The economic point of view}

Consider now the economic and social conditions under which these moral agents find themself. In his book The Inquiry into the Nature and Causes of the Wealth of Nations, Smith states that any individuals freedom depends on the existence of a free market, which can be commercialized without State intervention. In this system, it is natural for individuals to seek profit, a fact that controls all commerce and, consequently, the entire society. However, the pursuit of profit and the defense of a self-regulating market does not mean that Smith thinks exclusively in preventing incursions upon private property. For example, the core of Smith's thought also emphasizes the idea of protection against violations of the individual's feelings and integrity. Based on that, we must keep in mind that in Smith's model states economic progress requires not only the minimization of coercion, ${ }^{27}$ but also: $i$. improvements in living conditions and ii. eradication of poverty.

Aware of the destabilization that distributional issues can cause to economic progress, Adam Smith expresses concern about the improvement of living conditions (i.). Such an element can be observed when the idea of efficiency waves is presented, which occur when real wages rise, consequently increasing workers' freedom of choice $^{28}$. Through this phenomenon, individuals have more choices, "in years of plenty, servants frequently leave their masters, and trust their subsistence to what they can make by their own industry" ${ }^{29}$. Consequently, higher real wages guarantee not only people's power of choice, instead of living beyond the basic survival needs. In this perspective, economic progress would not only improve living conditions, but also reduce

26 See Fleischhacker, 2004, 2019; Raphael, 1973.

27 In regard to the minimization of coercion, Smith considers that the minimum of coercion towards the motives and actions of individuals would allow the greatest possible extension of the freedom of all, that is, the equal exercise of interests. In this sense, economic progress would be the guarantor of social harmony that takes precedence over innumerable freedoms, since everything that interferes with these is considered unfair and contrary to liberalism. He says, "the legislature, were it possible that its deliberations could be always directed, not by the clamorous importunity of partial interests, but by an extensive view of the general good, ought upon this very account, perhaps, to be particularly careful neither to establish any new monopolies". (Smith, 1776:616).

28 It is noteworthy that Adam Smith was a great critic of slavery, arguing that only wage labor is capable of promoting the wealth of a nation. For him, the accumulation of capital obtained through slave labor (common in the colonies of that time), did not produce wealth, since it did not encourage human flourishing. In light of this, he reveals that a nation's wealth is not only constituted by economic power, but also by the possibility of human flourishing that it promotes for the whole of society.

29 Smith, 1776:203. 


\section{Philosophy International Journal}

social disparities of work. As for wage differences, the philosopher claims that only legitimate differences are allowed, that is, those acceptable to the worker himself. These fair inequalities may occur in the labor market as long as the difference between remunerations obeys the individual's free choice and it cannot be an institutional policy of restriction. The point is that inequalities are reduced by increasing access to wealth, which is promoted by higher wages and, therefore, to promote progress need to concern. ${ }^{30}$

Equally, wage rates should not fall below a certain level in the long run, because "a man must always live by his work", ${ }^{31}$ revealing Smith's concern about the whole of society. For him, in the Progressive State, ${ }^{32}$ when society moves towards the acquisition of greater wealth, ${ }^{33}$ rather than when it is already rich, the poorest workers' situation is happier and more pleasant. Simply observe that in this situation there is a greater supply of labor and, consequently, more attractive remuneration. On the other hand, this same situation is precarious in the Stationary State and miserable in the Declining State. In this sense, the Progressive State will be the most favorable, as it will bring the greatest benefit to society, given that economic evolution allows the promotion of better lives for the less fortunate. ${ }^{34}$ Such an outcome is likely to be observed, since progress generates an increasing wage fund which consequently increases income and real wages. As a result, a Progressive State would lead to a better living condition for the poorest people ${ }^{35}$. In this

30 For Smith, it is unfair that the worker does not have access to the product of their work, "it is but equity, besides, that they who feed, clothe, and lodge the whole body of the people, should have such a share of the produce of their own labour as to be themselves tolerably well fed, clothed, and lodged". (Smith, 1776:115).

31 Smith, 1776:179. Such a statement reveals a concern with a salary compatible with something higher than the minimum necessary for the worker's subsistence.

32 Smith argues workers need to live with more than the basics, like food, for their survival. Considering that, the "Progressive State" will be the one that will bring the greatest benefit to society as a whole, given economic evolution would allow the promotion of improvements in life. On the other hand, the "Stationary State" and the "Declining State" are cruel to the poorest. (Cf. Smith, 1776: 119).

33 As discussed by Leonidas Montes in Adam Smith in Context: a critical reassessment of some central components of his thought, sometimes the "wealth" mentioned by Smith is much closer to Machiavelli's notion of "fortune", than the Economic idea of accumulating assets. In this sense, Montes argues, as demonstrated by Smith, the Machiavellian virtues had a strong influence on the development of Scottish Enlightenment thinking. See: Montes, 1966: 62.

34 See: Smith, 1776:200.

35 Furthermore, Smith recognizes that the market could have perverse effects on individuals' personal fulfillment, which could discourage their virtues, harming the whole of society. For him, the wealth of a community does not consist merely in the control at any time of physical properties or precious metals. That is a very reductive view of wealth, and it cannot explain the role of human labor in the accumulation of wealth. In this sense, wealth should be understood as ownership combined with our potential to earn more, also considering our potential to develop and refine case, dignified payment would be the merit for poor workers who, according to Smith, would need to have more than the minimum subsistence as a consideration of justice. ${ }^{36}$

The concern about poverty of nations ${ }^{37}$, in turn, is taking shape on the world stage (ii .). This discussion is not new, and Smith already contributed to this debate through concern with poverty, unemployment of the poor and collective hunger. In relation to the latter, the philosopher considers that it is not the traders who produce hunger. On the contrary, many of these outbreaks are not caused by a "real scarcity" 38 attributed to the decrease in food production, but by other processes unrelated to this. ${ }^{39}$ Despite the Scottish philosopher's concerns, his proposal was not intended to create rights for specific groups. Nevertheless, he recognizes the importance of eradicating poverty and the State avoids measures that promote it. In this sense, the State must take care of the ones in need making use of public institutions to deal with any problems that may arise. His concern is not only to solve subsistence problems, but also to provide life quality and the possibility for individual development, that will consequently ensure economic progress. For this, we can adopt the following structure,

P1. The accumulation of capital yields economic progress. P2. The accumulation of capital occurs through salaries.

HENCE,

skills, technologies and the ability to change our economic conditions However, the fact that progress is based on the extent of wealth does not mean that human beings and the nation develop only through the growth of financial or capital assets, as there are elements of human flourishing involved in this equation.

36 For Smith the increase in wealth also improves the living conditions of the poor population. Therefore, he stresses the importance of wages, "the wages of labour are the encouragement of industry, which, like every other human quality, improves in proportion to the encouragement it receives. A plentiful subsistence increases the bodily strength of the labourer, and the comfortable hope of bettering his condition, and of ending his days perhaps in ease and plenty, animates him to exert that strength to the utmost. Where wages are high, accordingly, we shall always find the workmen more active, diligent, and expeditious than where they are low". (Smith, 1776:119).

37 According to the Oxford dictionary, poverty is "the state of being extremely poor" or "the state of being inferior in quality or insufficient in amount". (https://en.oxforddictionaries.com/definition/poverty). Locke in the text An Essay on the Poor Law (1697), makes a distinction between 'charity' towards the poor from the idea of 'justice', demonstrating social concerns and indicating that the path to solving poverty is strengthening virtue and promoting work.

38 Smith apud Sen, 1999a:41.

39 For example, "by the waste of war, but by far the greatest number of cases by the fault of the seasons; and that a famine has never arisen from any other cause but the violence of government attempting, by improper means, to remedy the inconveniences of a dearth". (Smith, 1776:690). In addition to waste in wars and issues involving losses at the station, another much more relevant explanation for collective famines would be the values of wages, unemployment and the price of food. Such situations lead to overweight of the systems and associations that make up the affected community. 


\section{Philosophy International Journal}

The poor wage-earner without a salary harms economic progress (besides promoting perverse effects on the individual's personal achievement, discouraging his or her virtues). From this logic of the author's reasoning, we reinforce the idea that economic progress should generate more benefits for the less fortunate. Therefore, the State should and can intervene only to avoid such deficiencies ${ }^{40}$.

In addition, it is important to demystify the economic dimension of his theory, often mistakenly associated with the vision of pure self-interest ${ }^{41}$, downplaying the fact that for Smith the moveable cause of economic relationship is trust. ${ }^{42}$ For that, the moral point of view is important to relate his theory of moral sentiments, based on sympathy as the source of moral relationship, with elements of his economic theory present in the work Wealth of Nations. ${ }^{43}$ When read together we realized that the fundamental point of his theory is to demonstrate that self-interest cannot be considered the only sentiment that moves interpersonal relationships in the economy. ${ }^{44}$ The motivation for trade is not a defense of the mere search for obtaining individual advantages as assumed by rational choice theorists. ${ }^{45}$ Such a deduction stems from the misinterpretation of the sentence "It is not from the benevolence of the butcher, the brewer, or the baker, that we expect our dinner, but from their regard for their own interest" ${ }^{\prime 6}$ The basic error of these theorists is to read this passage as an excerpt from the theory. As a result, a distorted view of Smith's theoretical corpus has perpetuated itself. What this passage indicates is how commercial operations

40 "It should", because it has a social (and moral) concern involved and, "it can only", because there is a clear limit in the State intervention in society in Economic terms. See Verburg, 2000.

41 However, this Smithian self-interest should not, in cases of moral conflict, prevail over the highest interests of society. This greater interest shows that moral issues such as benevolence go beyond individual interests in favor of the collectivity. Therefore, even though self-interest is common to human nature, there is no parameter for that individual interest to be demanded above the interests of society as a whole.

42 See Arrow 1951; Sen, 2011.

43 According to Sen: "Even as Smith's pioneering investigations explained why (and particularly how) the dynamism of the market economy worked, they also brought out the support that the markets need from other institutions for efficacy and viability. He identified why the markets may need restraint, correction, and supplementation through other institutions for preventing instability, inequity, and poverty". (Sen, 2009b:53).

44 The sentiment of mutual confidence occurs "when the people of any particular country have such confidence in the fortune, probity, and prudence of a particular banker" Smith, apud, Sen, 2009b:55. (http://www. nybooks.com/articles/2009/03/26/capitalism-beyond-the-crisis/>).

45 Although there is an incisive study in the economic literature about the Smithian rational choice theory, even allowing for the creation of consequent theories, such as Sen's social choice theory, we will not dwell on it here. See: ARROW, K. (1951), Social choice and individual values e Amartya Sen (2011) The idea of Justice. Regarding the theory of rational choice, Sen says that "it consists only in the intelligent promotion of self-interest". (Sen, 2011:63).

46 Smith, 1776:95. take place, in other words, that negotiations with mutual advantages are common, and not that self-interest alone commands the economy. ${ }^{47}$

Furthermore, if we make a careful study of the word used by Smith, we will find the term exchange ${ }^{48}$ at the expense of distribution or production, demonstrating that his proposal is for a sustainable exchange, in which there is a strong interaction between people, as well as sociability. Of course, there are mutually advantageous negotiations in commercial operations, but this aspect takes the market as a starting point. When we consider the individuals, who carry out the exchanges, the conditions and virtues presupposed in them indicate that above all there must be trust in economic relations. ${ }^{49}$ This reinforces the idea that the motivation for the economy is predominantly related to the notion of confidence between social agents. This demonstrates how the Smithian economic dimension requires a moral perspective.

Thereby, I conclude that the understanding that Adam Smith would have eschewed social issues does not stand up to scrutiny of his writings..$^{50}$ On the contrary, much more than mere writings on liberalism and free markets, in Smith there is the defense of social justice that are reflected in his concerns about the damage that an excessive division of labor can cause to workers..$^{51}$ More than that, when morality enters the economic sphere of Smith's thought, we may find answers to alleviate contemporary problems such as the lack of confidence in the economy. Such assumptions help us better understand why nations may sometimes lose their credibility as well as indicate what sort of economic sentiment ${ }^{52}$ should permeate trade relations.

\section{Cf. Sen, 1999a:39.}

48 According to the Oxford dictionary, exchange can be termed as: "An act of giving one thing and receiving another (especially of the same kind) in return." Or "A system or market in which commercial transactions involving currency, shares, etc. can be carried out within or between countries". Link: https://en.oxforddictionaries.com/definition/exchange. Smith's focus is on the motivations of these exchanges and not on the production itself. See: Smith, 1776: 282.

49 In The Theory of Moral Sentiments Smith says "Nothing pleases us more than to observe in other men a fellow feeling with all the emotions of our own breast; nor are we ever so much shocked as by the appearance of the contrary". Smith, 1759:13.

50 Paim, 1998:45.

51 Stocker, 2009, Fleischacker, 2004, Griswold, 1999, Sen, 1999, 2009a. As Mumford noted, Smith is "a manifestation not only of a great mind, but of an entire age", whose challenges and solutions perpetrated by them manifest themselves in the most diverse ways in the social problems that we all experience today. Mumford, 1944:168. For Mumford, Smith was the man who made England, and then the entire Western world, understand how the market held society together, and the first to build a social order building, being the first theorist to formulate a scheme broadly and systematically.

52 See Emma Rothschild, Economic Sentiments: Adam Smith, Condorcet and the Enlightenment (2001). 


\section{Philosophy International Journal}

\section{Section 03: The political point of view}

Having clarified Smith's moral and economical core thoughts, I am interested in clarifying the political dimension of Smith's thesis as the locus where his liberal theory is developed. In this case, the discussion is no longer based on the relationship between moral or economic agents in a compartmentalized way. Now, the Archimedean point of the discussion is shifted to the political sphere, in which moral individuals, in cooperative economic relations, wonder about the limits of State in relation to social issues.

As I have seen the complete deregulation of the economy and the needs of society can cause perverse practices that generate poverty, hunger and war. Also, benefiting only specific groups, without a justification for doing so, can bring about a population extremely dependent on the State. This explains why the State has the duty, in a moral sense, to have a legitimate concern in terms of social justice with social issues, while this is the clear limit of its intervention on society.

There is a bias of distributive justice53 in Smith that does not intend to level society, but to avoid excesses, because a good institutional structure is enough to generate desirable distributive results. ${ }^{54}$ So, via effort and freedom, any individual will always be able to improve their living conditions in societies where public power governs based on "general principles," 55 preventing "a hundred impertinent obstructions with which the folly of human laws too often encumbers its operations" ${ }^{56}$ In this regard, the State would contribute to the enlightenment of the population, promoting virtues and human progress and hence improving the society in living conditions. ${ }^{57}$

For this, it is the State's duty to remove the harmful obstacles to human development, by guaranteeing public education as a "great antidote to the poison of enthusiasm and superstition", ${ }^{58}$ as well as to promote social progress and

53 Just to quote, Barry Stocker said: "There is distributive justice in Smith in the sense that he favours the distribution that emerges from freedom in economic activities, and in the state measures he favours to benefit the poor rather than the rich. However, that is not the same as the kind of belief in a predetermined pattern of distribution of justice which Rawlsians, or egalitarian liberal favour, at the extreme a completely flat distribution as argued for by G.A. Cohen and which is in the basic assumptions of Habermas thought on norms, ethics, and discourse". (Available at: https://www. adamsmith.org/blog/liberty-justice/adam-smith-and-distributive-justice).

54 Cf. Stocker (2009) Adam Smith, The City, Natural Order, Republicanism and Rosanvallon (1998) A nova questão social.

55 Smith, 1776:39.

56 Smith, 1776:43.

57 Berry, 1967; Haakonssen, 1996.

58 Smith, 1776:14. wealth. The public power has the duty to promote education, mainly Philosophy and Science, for the entire population, especially the poorest (inferior ranks). That is the best alternative to provide intellectual and social mobility for those to rise (to the middle ranks)..$^{59}$ Since the great cause of inequalities in the divisions of labor is not in relation to talent, but in being capable of carrying out the work the education assumes a rule prominence in his theory. In relation to the inequalities that are based on talent or innate abilities, these labor differences imply that people produce different things and, based on this reality, commerce and daily exchanges simply reveal that we are mutually dependent on each other for our livelihood and therefore we are all the same ${ }^{60}$ The reason is that most of the differences we see in people are not innate, but environmental:

The difference of natural talents in different men is, in reality, much less than we are aware of; and the very different genius which appears to distinguish men of different professions, when grown up to maturity, is not upon many occasions so much the cause as the effect of the division of labour. The difference between the most dissimilar characters, between a philosopher and a common street porter, for example, seems to arise not so much from nature as from habit, custom, and education. When they came into the world, and for the first six or eight years of their existence, they were, perhaps, very much alike, and neither their parents nor playfellows could perceive any remarkable difference. About that age, or soon after, they come to be employed in very different occupations. The difference of talents comes then to be taken notice of, and widens by degrees, till at last the vanity of the philosopher is willing to acknowledge scarce any resemblance. ${ }^{61}$

59 In accordance to Smith, "The third and last duty of the sovereign or commonwealth is that of erecting and maintaining those public institutions and those public works, which, though they may be in the highest degree advantageous to a great society, are, however, of such a nature that the profit could never repay the expense to any individual or small number of individuals, and which it therefore cannot be expected that any individual or small number of individuals should erect or maintain. (...).After the public institutions and public works necessary for the defense of the society, and for the administration of justice, both of which have already been mentioned, the other works and institutions of this kind are chiefly those for facilitating the commerce of the society, and those for promoting the instruction of the people." (Smith, 1776:963).

60 Regarding the Smithian belief that human capital, which will mainly reflect the differences between incomes, economist Anthony Atkinson in Inequality says: "What can be done? says that differences do not necessarily imply inequality and (...) it is quite possible that investment in human capital by a worker with higher education earns more (or less) than ordinary profit in the capital". (Atkinson, 2015:26).

61 Smith, 1776:32. For Smith, the difference between rich and poor is not concerned with what each consumes, since the rich do not consume much more than the poor, but the difference lies in the selectivity and quality of what is consumed. Smith says, "in what constitutes the real happiness of human life, they are in no respect inferior to those who would seem so much above them. In ease of body and peace of mind, all the different ranks of 


\section{Philosophy International Journal}

Put another way, different skills among people can vary according to the education each person received. For this reason, the philosopher values education as an institutional strategy for the social development of individuals, which avoids large wage differences, the overcoming of material inequalities, in addition to the development of a critical sense. The logical consequence of all this is the promotion of economic and social progress. ${ }^{62}$ Given this, we can say that market choices involve a complex of social and moral values that permeate such choices, as well as the regulations of the institutions.

In parts of Wealth of Nations, Smith defends free market, but considering him as a precursor to laissez-faire ${ }^{63}$ is at least doubtful. Indeed, Smith claims that the extremes of market liberalization have negative consequences as mentioned below:

The man whose whole life is spent in performing a few simple operations, of which the effects too are, perhaps, always the same, or very nearly the same, has no occasion to exert his understanding, or to exercise his invention in finding out expedients for removing difficulties which never occur. He naturally loses, therefore, the habit of such exertion, and generally becomes as stupid and ignorant as it is possible for a human creature to become. ${ }^{64}$

life are nearly upon a level, and the beggar, who suns himself by the side of the highway, possesses that security which kings are fighting for". (Smith, 1759:185).

62 However, in addition to education being a method to overcome material inequalities, it will also promote an individual process of learning self-control and developing moral virtues. Considering that, the idea that the Smith's theory would have given up on social issues does not stand up an examination of his writings, since his theory fails to support the pure selfsufficiency of the economy.

63 Laissez-faire, (French: allow to do) policy of minimum governmental interference in the economic affairs of individuals and society. The origin of the term is uncertain, but folklore suggests that it is derived from the answer Jean-Baptiste Colbert, comptroller general of finance under King Louis XIV of France, received when he asked industrialists what the government could do to help business: "Leave us alone." The doctrine of laissez-faire is usually associated with the economists known as Physiocrats, who flourished in France from about 1756 to 1778. For Rothschild, for example, the conservatism of the Smithian Enlightenment consists precisely in the movement to bring laissez-faire into the economic sphere. As a science focused on wealth. (See Rothschild, 2001:3). Nevertheless, his Enlightenment content was also based on progress in its moral, economic and freedom dimensions, considering its peripheral situation of Scotland in relation to the European world, and in the face of economic and social backwardness. In this sense, this proposal is a need to remove Scottish society from its situation of ignorance and miserability, while maintaining genuinely Scottish institutions and values and not a pure defense of laissez-faire. For Heilbroner in Economic Predictions, radical liberals at the University of Chicago (like Milton Friedman, Thomas Sowell and Friedrich Hayek) read only the first three books on Wealth of Nations and based libertarianism on this impoverished reading.

64 Smith, 1776: 417.
This excerpt demonstrates that the economic dimension should be not compartmentalized. So much so that Smith admits that the State ought to take the necessary measures to regulate the economy. This is explained by the history of mankind "in every improved and civilized society this is the state into which the labouring poor, that is, the great body of the people, must necessarily fall, unless the government takes some pains to prevent it". ${ }^{65}$ From the political point of view, it may be said that in Smith's theory of justice a fair, prosperous and harmonious society depends on agents with fair and cooperative behaviors. Such progress is only sustained through our own sympathy and recognition of the other as equal. This consequently promotes a feeling of tolerance towards the other. At the same time, it is the role of the State to promote the conditions for this to happen.

In addition, economic progress can be achieved by minimizing coercion, eradicating poverty, and improving living standards of the population. In such a case we are coming to a virtuous circle capable of generating social harmony and favorable conditions for the individual development of each person's life projects. In this sense, there is a moral justification for economic progress as a necessary means to produce order, not only in terms of social stability, but also as a fair society. Smith is enlightening: "no society can surely be flourishing and happy of which by far the greater part of the numbers are poor and miserable".66 Based on the consideration that all individuals are morally engaged in cooperating at the same time, the economic dimension of their social relations is adequately supplied by a balanced state. Sympathetic liberalism will be engendered as a consequence of this triad.

\section{Preliminary Conclusions}

As we have seen, in the moral dimension, sympathy will be understood as a kind of "organic connection" between people, for it allows the individual to put himself in another's place using the device of the imagination. Through this movement, it is possible to feel, to some extent, how one feels, enabling self-knowledge and the recognition of the other as an equal ${ }^{67}$. From an economic point of view, I need to keep in mind that one of the fundamental points of Smith's theory is the understanding that self-interest cannot be considered only the feeling that moves interpersonal relationships. There is the feeling of mutual trust, which is a condition for commercial relations and economic progress. Finally, the political dimension excels in virtuous societies and, for that, requires cooperative subjects and fair behavior. The need for
65 Idem, ibidem.
66 Smith, 1759:115.
67 According to Smith, sympathy will be developed throughout experience, being flourished by habit. 
sympathy will occur, in this sphere, with a view to promoting the recognition of the other that generates individuals morally engaged in cooperating. So, sympathy must be taught and aroused both at home and by educational institutions. For that, Smith would endorse State intervention so that everyone can have an education, signaling a distributive social justice bias ${ }^{68}$.

For all these reasons, sympathy is the feeling capable of promoting self-knowledge and the recognition of the other as an equal to me. In turn, this feeling will provide social interaction with solidarity agents and reduce prejudice. In addition, the feeling of belonging to the community may flourish and, consequently, people will feel more motivated to cooperate and to adopt just behaviors, which is a sine qua non condition for a peaceful and prosperous society. ${ }^{69}$ In essence, the idea of a tripartite theory in Smith is due to interconnection of the moral, economic and political spheres in his thought and this center on our thesis of a sympathetic version of liberalism. This idea arises in the moral sphere of his thought and promotes the balance among the other spheres of his triad. In other words, both economics and politics will depend on morality. ${ }^{70}$

In the end, if I think about the feeling of sympathy contemporaneously and in global terms, I can see that this feeling combined with impartiality could allow us to understand the perspective of the other, regardless of the cultural differences that permeate the world. Considering that it is impossible to form an adequate moral judgment without the necessary presence of the binary me/other, mediated by sympathy, the limit of action would be the feature that separates such subjectivities. Thus, to the extent I understand the other and his motivations for action, I recognize and reaffirm his and my identity. Therefore, this movement promotes sociability and the social, political and legal recognition of outsides beyond borders. So, I realize that the

68 Through sympathy, we are able to offer alternatives that can alleviate contemporary problems, such as: economic crisis, intolerance, disrespect and civil and international conflicts. Suffice it to consider that economic crises are often due to a lack of trust between people and countries. Therefore, since trust originates from mutual sympathy, as it starts to be promoted, economic relations become more developed and, consequently, propitiate the wealth of the nation. This development will allow both the improvement of the population's life and the reduction of poverty. In political terms, life in society is more harmonious when there is mutual respect.

69 In this case, we move from private morality (being sympathetic to people in need) to institutional morality (it is the state's duty to ensure people's basic conditions for living). That, therefore, would be a common interest/public interest based on a moral feeling which inadvertently promotes my self-interest, therefore, being mutually advantageous. That is the case then enlarging the role of sympathy to the State is not only beneficial to society as a whole but to myself, for it is in my interest to live in a stable, fair and harmonious society.

70 See Samuel Fleischacker (2019), Being me being you: Adam Smith \& Empathy. identity argument will provide a notion of ethics of humanity shared with those not belonging to the local community. As I expand my perspectives, I get rid of prejudices, bringing contributions to the global public discussion required in the globalized world. In this perspective, the political dimension must offer social conditions for the difficult task of combining individual and collective rights, or dominant culture.

In the tension between different conflicts of beliefs, sympathy finds its locus and proves to be extremely current as a reliever of strained relationships. As diversity is socially recognized, legal pluralism is strengthened, promoting justice beyond the frontier of the State, that must be concerned with guaranteeing a more inclusive and harmonious society. The recognition of the other will be a vital requirement for the promotion of the democratization of public spaces. It is enough to consider that an economic crisis is also a reflection of the lack of trust between countries (internationally) and between equals (nationally). And the mutual sympathy, which generates trust, which is the basis for economic relations, would favor the development of the nation and, consequently, the improvement of the population's life. ${ }^{71}$

Certainly, seems interesting to promote values that are both moral and political in society as a whole ${ }^{72}$. For these virtues, we must foster sympathy propitiating contributions of political and economic points of view. This movement could promote cooperation and seek to promote education for sympathy for all the social and emotional benefits it can bring. Sympathetic liberalism becomes an ideal theory with principles of justice that seek to address contemporary problems. Understanding that Smith's theory can deal with economic and political issues via sympathy, I appropriate this concept and transfer it to the contemporary social and political sphere. Making this development I can adapt it to the current reality and the problems I deal with. The key point of this idea is to make people feel motivated to cooperate. More than that, people need to be engaged in this cooperation, feeling they belong to society. Otherwise, no person can genuinely think for the good of all society ${ }^{73}$.

71 It is the feeling of mutual sympathy enlarged to nations. When dealing with the international economy and exchanging goods sympathy is implied in those relations.

72 It is also worth noting this notion of sociability present in Smith's commercial societies defense will be geared towards the social virtues that he defended in Wealth of Nations. In turn, the so-called social virtues are the civic virtues of justice, prudence, self-control and benevolence that will be the gear for the development of individuals and society. I also highlight that such civic (or social) virtues are anchored in his moral virtues - about which Smith writes which may foster the feeling of justice, the recognition of the other and solidarity among individuals and the different nations, which promotes a humanistic dimension of their thinking. They are the gears for Adam Smith's commercial companies, revealing once again the tripartite movement.

73 The development of good virtues is an interesting alternative to seek 
In this sense, it is useless to focus on the minimum that Smith himself proposes for, if people do not feel compelled to help. ${ }^{74}$ Therefore, theories that aim only at promoting resources, without considering people's feelings towards society are ineffective. ${ }^{75}$ It is not a question of shaping human behaviors, but of contributing a theory that can help human dispositions, since we can start from the idea that everyone is capable of developing sympathy. ${ }^{76}$ So, we are all in a position to develop it, regardless of which origin of that feeling we want to adopt $\mathrm{t}^{77}$ to a lesser or greater degree ${ }^{78}$. For all of that, I concluded sympathetic liberalism is a political model based on Smith's tripartite theory that could effectively deal with contemporary problems.

\section{References}

1. Atkinson A (2015) Inequality: what can be done? Harvard University Press.

2. Arrow K (1951) Social choice and individual values. Yale University Press.

to produce a more harmonious country. For example, if you try to develop good feelings against corruption, that movement can solve other types of problems. This movement would require habits to practice constant virtues.

74 For example, think of public policies like quotas. Often the problem is not only social, it is also recognized in society and that recognition depends on the other.

75 Like Dworkin and Rawls, even theories like Sen, which attempt to address moral and economic issues are insufficient to account for human behavior.

76 Considering the key of sympathy in Smithian thought, analyzing its locus will offer different implications of evolutionary metaethics, because the recognition that evolutionary forces have shaped our psychological structure, influencing the way we make moral judgments, allows agents "To discern the remote consequences of all our actions, and to anticipate the benefit or loss that is likely to result from them". Thus, in affirming that sympathy is built up through experience and habit, and should be promoted both at school and at home, Adam Smith seems to agree with Sharon Street about the relationship between evolutionary pressure and moral judgments. Faced with the influence engendered by the evolutionary link, the Smithian subject appears to be constantly facing a game of mirrors that reflects the exercise of sympathy as a continuous mediator of social relationships. Based on that, there is a constant need to develop this feeling. In turn, people, when observing the behaviors and reactions to certain types of actions and feelings of others, assimilate patterns of judgment that make the exercise of capturing the feelings of others make it possible both to apprehend moral standards and to apply them. Given the diversity of aspects involved in the locus of sympathy, education once again becomes necessary for a prosperous nation.

77 Even people who are biologically prone to not being friendly, like autistic people, for example, there are ways to develop through pedagogical practices. In other words, with the development of social virtues, sociability and, mainly, the promotion of a school, cultural education (using the media, for example), for the development of this civic and solidary notion.

78 Nevertheless, those countries where there are inequalities, sympathetic liberalism could do if the center were respected. Even poor nations can benefit from the sympathetic justice of contemporary societies, which benefits everyone.
3. Bard K (2007) Neonatal imitation in chimpanzees (Pan troglodytes) tested with two paradigms. Animal Cognition 10(2): 233-242.

4. Berry C (1967) Smith and Science. The Cambridge Companion to Adam Smith. University of California Press.

5. Brahan M (2006) Adam Smith's Concept of social justice. Institute of Social Economics.

6. Breban L, Gilardone M, Walraevens BA (2015) missing touch of Adam Smith in Amartya Sen's Public Reasoning: the man within for the man without. Laboratoire d'Économie Dionysien.

7. Brien DP (1976) The longevity of Adam Smith's vision: paradigms, research programs and falsifiability in the history of economic thought. Scottish Journal of Political Economy 23(2): 133-151.

8. Coase R (1976) Adam Smith's View of Man. Journal of Law and Economics 19(3): 529-546.

9. Comim F (2002) The Scottish Tradition in Economics and the Role of Common Sense in Adam Smith's Thought. Review of Political Economy 14(1): 91-114.

10. Darwall S (1983) Impartial Reason. Cornell University Press.

11. Darwall S (1999) Sympathetic Liberalism: Recent Work on Adam Smith. Philosophy and Public Affairs 28(2): $139-164$.

12. Devine D (1977) Adam Smith and the Problem of Justice in Capitalist Society. Journal of Legal Studies 6(2): 399409.

13. DumontL (1977) Homo Aequalis: genèse etépanouissemnt de l'ideologie économique. Gallimard.

14. Dupuy JP (1922) Le Sacrifice et l'envie. Le libéralisme aux prises de la Justice. Calmann-Levy.

15. Evensky Jerry (1986) Adam Smith's Lost Legacy. Clarendon Press.

16. Evensky Jerry (2015) Adam Smith's Wealth of Nation. Cambridge University.

17. Fleischacker S (2004) On Adam Smith's Wealth of Nations: A Philosophical Companion. Princeton University Press.

18. Fleischacker S (2019) Being Me Being You: Adam Smith and Empathy. The University of Chicago Press.

19. Fogle T (1990) Are genes units of inheritance?. Biology 


\section{Philosophy International Journal}

and Philosophy 5: 349-371.

20. Griswold JR Charles (1999) Adam Smith and the virtues of enlightenment. Cambridge University Press.

21. Grossi Paolo (2007) Legal Mythologies of Modernity. Boiteux Foundation.

22. Guimarães Moreira (2000) 0 conceito sistêmico de gene - uma década depois. Auto-organização: estudos interdisciplinares. CLEUnicamp 2: 248-280.

23. Haakonssen Knud (1996) Natural law and moral philosophy: from Grotius to the Scottish enlightenment. Cambridge University Press.

24. Heilbrooner (1986) The Essential Adam Smith. WW Norton.

25. Holler M (2006) Adam Smith's Model of Man and Why the Market Program Failed. Acta Philosophica Fennica.

26. Hont I, Ignatieff M (1983) Wealth and Virtue: The Shaping of Political Economy in the Scottish Enlightenment. Cambridge University Press.

27. Keller EF (2005) The century beyond the gene. Journal of Biosciences 30(1): 3-10.

28. Laland K, Brown G (2002) Sense and Nonsense: Evolutionary Perspectives on Human Behavior. Oxford University Press.

29. Locke J (1997) An essay on the poor law. Political Essays. Cambridge University Press.

30. Montes Leonidas (1966) Adam Smith in context: a critical reassessment of some central components of his thought.

31. Moos S (1983) Is Adam Smith out of date?. In: WOOD John C (Ed.), Adam Smith: critical assessments, Routledge.

32. Morrow G (1924) The significance of the Doctrine of sympathy in Hume and Adam Smith. Philosophical Review 32(1): 60-78.

33. (1969) The Ethical and Economic Theory of Adam Smith. Longmans, Green and Co.

34. Muller Jerry Z (1995) Adam Smith in his time and ours: designing the decent society. Princeton Univ Press.

35. Mumford L (1944) The Condition of Man. Harcourt, Brace \& World.

36. OXFORD, Dictionary.
37. Paim A (1981) Temas atuais: A questão do socialismo, hoje. Convívio.

38. Portin P (1993) The concept of the gene: short history and present status. Quarterly Review of Biology 68(2) 173-223.

39. Preston S, Waal F (2002) Empathy: Its ultimate and proximate bases. Behavioral and brain sciences 25(1): 1-20.

40. Raphael D (1973) Hume and Adam Smith on Justice and Utility. Proceeding of the Aristotelian Society 73(1): 87104.

41. Raphael D (2007) The impartial Spectator: Adam Smith's Moral philosophy. Clarendon Press.

42. Rosanvallon Pierre (1998) The new social question: rethinking the welfare state. Princeton University Press.

43. Rothschild E (2001) Economic Sentiments: Adam Smith, Condorcet and the Enlightenment. Harvard University Press.

44. Sayre Mccord Geoffrey (2013) The Moral Argument Against Moral Dilemmas. UNC Philosophy.

45. Sayre Mccord Geoffrey (2014) Hume and Smith on Sympathy, Approbation, and Moral Judgment. Social Philosophy and Policy 30(1-2): 208-236.

46. Sayre Mccord Geoffrey (2018) On a Theory of a Better Moral Theory and a Better Theory of Morality. UNC Philosophy, pp: 01-18.

47. Sayre Mccord Geoffrey (2015) Rational Agency and the Nature of Normative Concepts. UNC Philosophy, pp: 0116.

48. Sayre Mccord Geoffrey (2010) Sentiments and Spectators: Adam Smith's Theory of Moral Judgmentin. The Philosophy of Adam Smith, pp: 124-144.

49. Sayre Mccord Geoffrey (2009) Skepticism About Moral Knowledge. UNC Philosophy, pp: 01-24.

50. Brennan Geoffrey (2013) On “Cooperation". UNC Philosophy.

51. Smith Michael (2012) Desires...and Beliefs...of One's Own. Rational and Social Agency: Essays on Philosophy. Oxford University Press: Cambridge.

52. Sen Amartya (2010) Adam Smith and the Contemporary World. Erasmus Journal for Philosophy and Economics 3(1): 50-67. 
53. Sen Amartya (2009a) Adam Smith's market never stood alone. The Financial Times.

54. Sen Amartya (1986) Adam Smith's Prudence. Theory and Reality in Development. MacMillan.

55. Sen Amartya (2011) A ideia de justiça. Companhia das letras.

56. Sen Amartya (1999) About ethics and economics. Companhia das letras.

57. Sen Amartya (2009b) Capitalism Beyond the crisis. NYREV.

58. Sen Amartya (2000) Development as freedom. Companhia das Letras.

59. Sen Amartya (1987) On ethics and economics. Clarendon Press.

60. Sen Amartya (1981) Poverty and Famines: An Essay on Entitlement and Deprivation. Clarendon Press Oxford.

61. Sen Amartya (1992) Reexamined inequality. Rio de Janeiro: Record.

62. Sidgwick H (2020) Altruism. Stanford Encyclopedia of Philosophy.

63. Sidgwick H (1981) The Methods of Ethics. Hackett Publishing Company.

64. Smith Adam (1776) An Inquiry into the Nature and Causes of the Wealth of Nations. The University of Chicago Press.

65. Smith Adam (1763) Lecture on Jurisprudence. Clarendon Press.
66. Smith Adam (1999) O Inquérito sobre a natureza e as causas da Riqueza das Nações. Fundação Calouste Gulbenkian.

67. Smith Adam (1999) Teoria dos Sentimentos Morais. Wmf Martins Fontes.

68. Smith Adam (1759) The Theory of Moral Sentiments. Cambridge University Press.

69. Stocker B (2009) Adam Smith, the city, natural order, republicanism. Stockerblog.

70. Street Sharon (2006) A darwinian dilemma for realist theories of value. Philosophical Studies 127(1): 109-166.

71. Verburg R (2000) Adam Smith's growing concern about the issue of distributive justice. The European Journal of the History of Economic Thought 7(1): 23-44.

72. Venter C (2001) The sequence of the human genome. Science 291(5507): 1305-1351.

73. Williams G (1966) Adaptation and Natural Selection: a critique of some current evolutionary thought. Princeton University Press.

74. Winch D (1978) Adam Smith's Politics: An essay in Historiographic Revision. Cambridge University Press.

75. Witzum A (1977) Distributive Considerations in Smith's Conception of Economic Justice. Economics and Philosophy 13(2): 241-259.

76. Young J (1997) Economics as a Moral Science: the political economy of Adam Smith. Edward Elgar. 